\title{
GENOTOXICITY OF SHALLOW WATERS NEAR THE BRAZILIAN ANTARCTIC STATION "COMANDANTE FERRAZ" (EACF), ADMIRALTY BAY, KING GEORGE ISLAND, ANTARCTICA
}

\author{
Arthur José da Silva Rocha, Marina Tenório Botelho*, Fabio Matsu Hasue, Maria José de Arruda Campos \\ Rocha Passos, Caroline Patricio Vignardi, Phan Van Ngan and Vicente Gomes* \\ Instituto Oceanográfico da Universidade de São Paulo \\ (Praça do Oceanográfico, 191, 05508-120 São Paulo, SP, Brasil) \\ *Corresponding author: vicgomes@usp.br
}

http://dx.doi.org/10.1590/S1679-87592015080906301

\begin{abstract}
A B S T R A C T
Series of biomonitoring surveys were undertaken weekly in February 2012 to investigate the genotoxicity of the shallow waters around the Brazilian Antarctic Station "Comandante Ferraz" (EACF). The comet assay was applied to assess the damage to the DNA of hemocytes of the crustacean amphipods Gondogeneia antarctica collected from shallow waters near the Fuel Tanks (FT) and Sewage Treatment Outflow (STO) of the research station, and compare it to the DNA damage of animals from Punta Plaza (PPL) and Yellow Point (YP), natural sites far from the EACF defined as experimental controls. The damage to the DNA of hemocytes of G. antarctica was not significantly different between sites in the biomonitoring surveys I and II. In survey III, the damage to the DNA of animals captured in shallow waters near the Fuel Tanks (FT) and Sewage Treatment Outflow (STO) was significantly higher than that of the control site of Punta Plaza (PPL). In biomonitoring survey IV, a significant difference was detected only between the FT and PPL sites. Results demonstrated that the shallow waters in front of the station may be genotoxic and that the comet assay and hemocytes of $G$. antarctica are useful tools for assessing genotoxicity in biomonitoring studies of Antarctic marine coastal habitats.
\end{abstract}

\section{R ESUMO}

Séries de biomonitoramentos foram executadas semanalmente, durante o mês de fevereiro de 2012, para se investigar a genotoxicidade de ambientes costeiros rasos no entorno da Estação Antártica "Comandante Ferraz (EACF). O ensaio cometa foi aplicado para se avaliar os danos ao DNA hemocitário de crustáceos anfípodes Gondogeneia antarctica coletados em áreas rasas próximas aos tanques de armazenamento de combustível (FT) e saída de efluentes da estação de tratamento de esgoto (STO), em comparação aos danos ao DNA de animais provenientes de Punta Plaza (PPL) e Yellow Point (YP), locais naturais distantes da EACF, definidos como controles experimentais. O dano ao DNA hemocitário de G. antarctica não foi significativamente diferente entre locais, nos biomonitoramentos I e II. No biomonitoramento III, o dano ao DNA de animais coletados em águas rasas próximas aos tanques de combustível e saída de efluentes de esgoto foi significativamente maior do que aquele do controle de Punta Plaza. No biomonitoramento IV, a diferença foi significativa somente entre os locais dos tanques de combustível e de Punta Plaza. Estes resultados demonstram que a contaminação das águas em frente à EACF pode ser genotóxica e que, tanto o ensaio cometa quanto os hemócitos de $G$. antarctica são ferramentas úteis na avaliação da genotoxicidade em estudos de biomonitoramento de habitats marinhos costeiros da Antártica.

Descriptors: Antarctica, Environmental biomonitoring, Gondogeneia antarctica, Genotoxicity, Cometassay.

Descritores: Antarctica, Biomonitoramento ambiental, Gondogeneia antarctica, Genotoxicidade, ensaio cometa.

\section{INTRODUCTION}

The Antarctic region is one of the best preserved environments in the world, located far from the other continents and relatively free from their massive human presence and its consequent influence. However, environmental impacts resulting from human activities in Antarctica such as fishing, tourism 
and research are almost inevitable. The use of fossil fuels for the energy supply to ships (both tourist and research vessels) and around 79 near-shore research stations, as well as their sewage outflow are responsible for the contamination of Antarctic coastal waters. A wide range of pollutants, such as hydrocarbons (CRIPPS and PRIDDLE, 1991), persistent organic contaminants (WEBER and GOERKE, 2003) and others from sewage effluents (HUGHES, 2004; HUGHES and THOMPSON, 2004) have been found in shallow waters and sediments of the benthic habitats near the areas occupied by research stations. The Brazilian Antarctic Station "Comandante Ferraz" (EACF) is a permanent establishment that houses from an average of 20 people in winter, to around 60 to 80 during the summer season (BÍCEGO et al., 2009). It is located on the Keller Peninsula in Admiralty Bay, King George Island, South Shetland, whose adjacent marine environment is inhabited from its shallows to $500 \mathrm{~m}$ deep by a variety of organisms (NONATO et al., 2000; FREIRE, et al., 2005).

Several studies have demonstrated the contamination of the marine environment around the EACF station by a wide range of pollutants, such as hydrocarbons (MARTINS et al., 2004), polychlorinated biphenyls (MONTONE et al., 2001), as well as faecal sterols and linear alkylbenzenes (MARTINS et al., 2002; MARTINS et al., 2012). Most of these pollutants are potentially genotoxic substances that interact with the DNA molecule inducing the formation of micronucleus (micronuclei?) (PHAN et al., 2007), DNA strand breaks (ROCHA et al., 2012a, b) and may lead to genetic mutations (OHE et al., 2004), whose constraints to the living organisms may have adverse effects on ecosystem stability (ANDERSON et al., 1994; BOURRET et al., 2008).

Antarctic marine ectotherms are usually animals with short reproductive seasons, low larval dispersal and low fecundity as well as being subject to marked variation of seasonal factors such as light intensity and food availability (KING and RIDDLE, 2001). Their long evolutionary adaptation to a stable environment at low temperature makes these animals sensitive to disturbances in natural factors, and also makes them suitable bioindicators of environmental quality. Gondogeneia antarctica, the species selected for this study, is one of the most abundant amphipod crustaceans in the intertidal region of Antarctic coastal waters. It is of sedentary habits and feeds on the macroalgae and debris of the surf zone (OPALINSKI and JAZDZEWSKI, 1978; JAZDZEWSKI, 1993; OPALINSKI and SICINSKI, 1995). In addition, these small crustaceans are important elements in the food web, being preyed on by other invertebrates (GOMES et al., 2009) and small fishes (BARRERA-ORO and
PIACENTINO, 2007; BARRERA-ORO and WINTER, 2008).

The environmental monitoring of Antarctic regions occupied by signatory countries is a goal of the Antarctic Treaty (SANTOS et al., 2006; PHAN et al., 2007; GOMES et al., 2009; 2012). Thus it is that the Brazilian Antarctic Program has given its support to studies on environmental monitoring to assess and mitigate impacts caused by the human presence on the environment and the organisms that inhabit it (MARTINS et al., 2012; PHAN et al., 2007). Xenobiotic-induced genotoxicity in aquatic organisms is often assessed using Single Cell Gel Electrophoresis (SCGE), a quick method commonly known as comet assay that estimates DNA fragmentation and repair mechanisms (LEMIERE et al., 2005; TICE, 1995). In the comet assay, DNA of a previously lysed cell is unwound in highly alkaline solution and submitted to electrophoresis. The relaxed and negatively charged fragments of DNA migrate away from the nucleoids, towards the anode. After staining, nucleoids and migrated fragments appear as the respective head and tail of a comet. The greater the quantity and the distance of the migrated fragments the greater is the degree of damage to the DNA.

This study aims to investigate the genotoxicity of the shallow marine waters off the Brazilian Antarctic Research Station in Admiralty Bay using a comet assay to evaluate DNA damage tohemocytes of $G$. antarctica collected at different sites in these waters.

\section{Material ANd Methods}

Gondogeneia antarctica amphipods were captured by handnet in shallow waters of Admiralty Bay, King George Island $\left(62^{\circ} 05^{\prime} \mathrm{S}, 58^{\circ} 23^{\top} \mathrm{W}\right)$, at four different locations (Fig. 1). Punta Plaza (PPL) and Yellow Point (YP) are located at adistance from the EACF and were established as control sites forcomparison with the area of possible influence of the fuel tanks (FT) and sewage treatment outflow (STO) sites in front of the Station. Sampling was carried out weekly during February 2012, rendering a total of four samples designated biomonitoring I, II, III and IV. Four animals were selected from each site per biomonitoring for the assessment of DNA damage by employing the alkaline comet assay described by SINGH et al. (1998), with slight modifications. Briefly, a small drop of hemolymph was individually sampled by puncturing the pericardia with the aid of acupuncture needles. Drops of hemolymph were suspended in $10 \mu \mathrm{L}$ of cooled phosphate buffer solution (PBS - pH 7.4), then mixed with $90 \mu \mathrm{L}$ of low melting point agarose (LMP $-37^{\circ} \mathrm{C}$ ) in PBS, and spread on the surface of a glass slide previously coated with $1 \%$ normal melting point agarose (NMP $-60^{\circ} \mathrm{C}$ ) 
in distilled water. The slides were covered with cover glass and kept at $4^{\circ} \mathrm{C}$ in the dark for $20 \mathrm{~min}$ until the solidification of the LMP gel. Then the cover glass was removed and the slides with the agarose gel layers were immersed in a lysing solution $(2.5 \mathrm{M} \mathrm{NaCl}, 100$ M EDTA, 10 mMTris, $1 \%$ Triton X-100, 10\% DMSO, $\mathrm{pH} 10$ ) in the dark for $2 \mathrm{~h}$. The slides were then washed with cooled PBS solution and transferred to the electrophoretic chamber filled with alkaline electrophoresis buffer (Na2 EDTA 1 mM, NaOH 300 $\mathrm{mM}, \mathrm{pH}>13$ ) for $10 \mathrm{~min}$ for DNA unwinding prior to electrophoresis. Electrophoresis was performed in the same buffer for $20 \mathrm{~min}$ at $20 \mathrm{~V}(0.71 \mathrm{~V} \mathrm{~cm}-1)$ and 300 $\mathrm{mA}$. After electrophoresis, the slides were washed with neutralizing solution (Tris $0.4 \mathrm{M}, \mathrm{pH}$ 7.5) followed by the silver staining method described by GARCÍA et al. (2004). Comets were photographed using the SAMSUNG SDF 312® digital camera attached to a Nikon ${ }^{\circledR}$ optical microscope and supported by the Ulead Video Studio 7 SE Basic ${ }^{\circledR}$ software for the digitalization of the images. Positive images of the comets were inverted to negative images foranalysis by the free software "CometScoreTM TriTek Corporation" (www.autocomet.com). One hundred cells were measured per slide and DNA damage was expressed as mean $( \pm \mathrm{SD})$ tail moment $\mathrm{TM}$, i.e. the comet tail length multiplied by the proportion of DNA in the tail (LEE and STEINERT, 2003). Homogeneity of variances was checked byLavene's test and significant differences between groups (sites or biomonitorings) were determined by the analysis of variance ANOVA, followed by the Newman Keuls test $(\mathrm{p}<0.05)$.

\section{RESUlts}

Mean tailmoment (TM) of hemocytic DNA of $G$. antarctica collected at the four sites studied during the four biomonitorings are shown in Figure 2. Differences in the TM were not significant between the four sites during the biomonitorings I and II. However, in biomonitoring III, DNA damage of hemocytes of $G$. antarctica collected from waters in front ofthe fuel tanks (FT) and at the sewage outflow (STO) increased significantly as compared to that of animals from the control site of Punta Plaza (PPL). Regarding comparisons with Yellow Point (YP), the differences in the mean TM of animals either from fuel tanks (FT) or from the sewage treatment outflow (STO) were not significant. In addition, there were no significant differences between PPL and YP, norbetween FT and STO sites. In biomonitoring IV, the DNA damage to hemocytes of $G$. antarctica collected from the FT site was significantly greater than that of animals from the PPL control site, the remaining comparisons being of no significance. Regarding comparisons between the biomonitorings, significant differences in the DNA damage to the hemocytes of $G$. antarctica sampled from PPL were noted (Fig. 3). The mean TM of animals from the PPL control site decreased significantly between biomonitorings I, II and III. The mean TM of biomonitoring IV was only of less significance than that of biomonitoring I. For the other sites, differences between the biomonitorings were not significant.

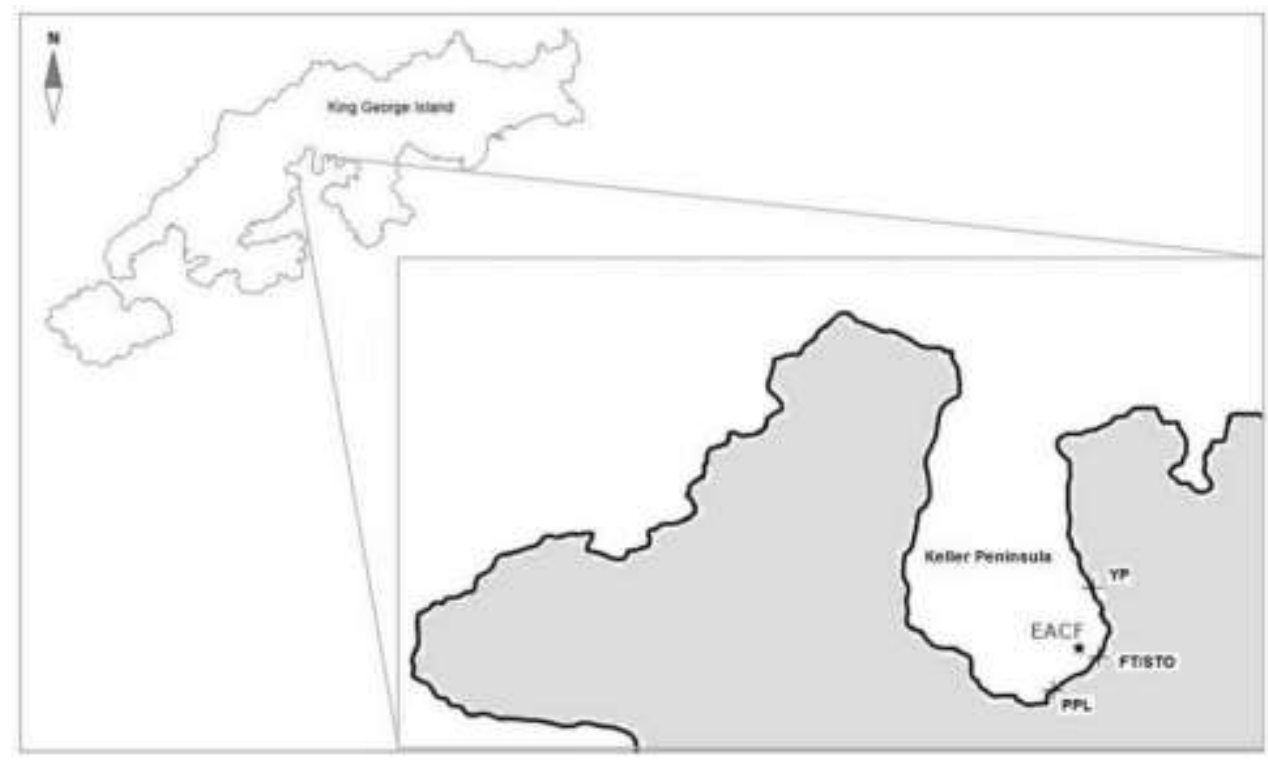

Fig. 1. Map of the Keller Peninsula, King George Island, Antarctic, showing the sampling places: YP: Yellow Point; FT - Fuel Tanks; STO - Sewage Treatment Outflow; PPL - Punta Plaza. 


\section{DisCUSSION}

Biomonitoring studies require systems that describe the environment quantitatively and qualitatively. Organisms that are in direct contact with pollutants may be suitable bioindicators (RAJAGURU et al., 2003). Among invertebrates, many crustaceans are able to metabolize xenobiotics such as PAHs due to a well-developed cytochrome P450 enzyme system (JAMES and BOYLE, 1998; LIVINGSTONE, 1998; MARTÍN-DÍAZ et al., 2008). This enzymatic system acts in phase I metabolism by adding functional groups through the oxidation, reduction or hydrolysis of non-reactive xenobiotics, converting them into activated metabolites capable of conjugating with water-soluble groups so as to be excreted by phase II metabolism (LISKA, 1998). However, these phase I enzyme-activated metabolites can also bind to DNA and cause genotoxicity by changing their molecular structure (VERMEULEN, 1996). DNA damage is a primary concern for the assessment of pollutionrelated stress in living organisms (KLOBUČAR et al., 2003).

Comet assays have been applied to assess the effects of toxicity on different forms of marine organisms (DE BOECK and KIRSCH-VOLDERS, 1997; HARTL et al., 2007; JHA et al. 2005; TABAN et al., 2004), including crustaceans (BIHARI and FAFANĐEL, 2004; KUZMICK et al., 2007; ROCHA et al., 2012b). Fluorescent dyes, such as ethidium bromide, DAPI, acridine orange and propididum bromide are the most common dyes used to visualize comets that must be analyzed by fluorescence microscopy before the staining bleaches out. In this study we used the silver staining protocol as described by GARCÍA et al. (2004; 2007), that keeps the comets stained for a long time for subsequent analyses under a conventional microscope. The extent of DNA damage is often assessed by digital image analyses, which provides relative DNA percentages in the head and tail, as useful data to express results (COLLINS, 2004; HARTMANN et al., 2003). The protocol employed in this study revealed comets with a clear distinction between the head and tail, as well as a sharp contour, which helped the accuracy of the analysis of the comets of $G$. antarcticahemocytes by the CometScore-TM free-use software.

The shallow waters and bottom sediments near the EACF are frequently characterized by high levels of petroleum hydrocarbons and other organic contaminants (BÍCEGO et al., 1996; MARTINS, et al., 2004), as well as slightly elevated levels of inorganic compounds, such as heavy metals and metalloids (SANTOS et al., 2005; RIBEIRO et al., 2011), as a consequence of the EACF's operations. Significant results noted in the DNA damage to $G$. antarctica collected from FT and STO sites in biomonitorings III and IV (Fig. 2) are similar to those reported by GOMES et al .(2012) with Trematomous newnesi fish caged at the same places. According to the authors, significant DNA damage to animals from FT and STO indicates that the contamination of these sites is localized, since they are less than $1 \mathrm{~km}$ from the PPL and YP control sites.

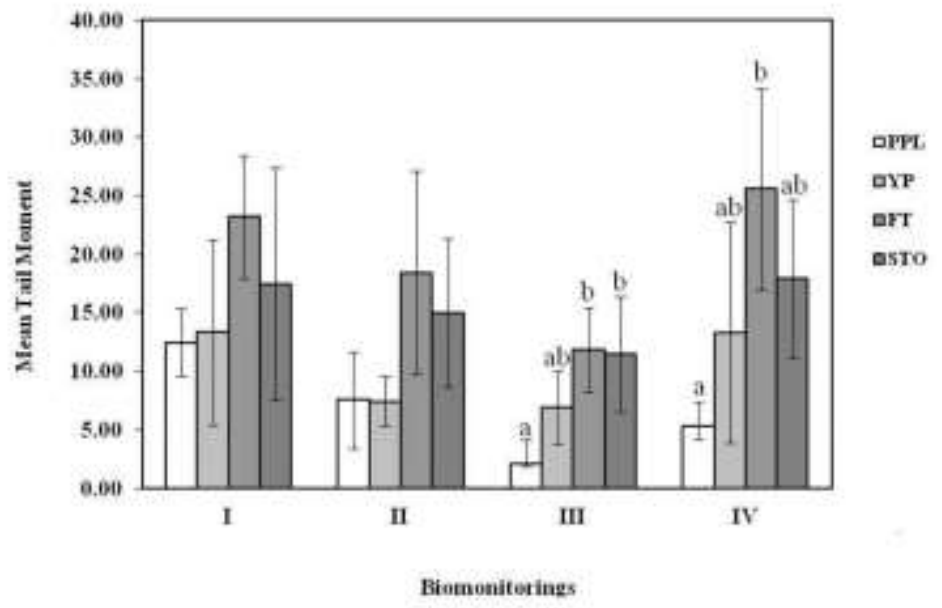

Fig. 2. Mean $( \pm \mathrm{SD})$ Tail Moment of hemocytes DNA of Gondogeneia antarctica in the four biomonitorings at the different sampling sites. Different letters denote significant differences $(\mathrm{p}<0.05)$ between places. 
Different hydrocarbon compounds have been found at the sea bottom as well as in the water samples near the fuel tanks, as resulting from the direct input by fuel leakage or from the combustion of fossil fuels (BÍCEGO et al., 2009). Table 1 presents ranges of organic compounds in sediments of the shallow waters around the Brazilian Antarctic Research Station obtained in some studies along the 12 years of observation. The lowest values of contaminants correspond to those found in areas far from the influence of the EACF. Elevated levels of fecal sterols were found nearby the EACF sewage effluent outflow, although lower than those measured before the period 2005-2006, when the improvements made to the sewage treatment system came intooperation (MARTINS et al., 2012). However, levels of alkylbenzesulphonates are still high relative to the more pristine areas, even after the improvements made to the station's sewage treatment system. In spite of the distinct contamination processes affecting the waters around the FT and STO, the effects in terms of DNA damage were similar in animals sampled from both these places. Differences in DNA damage could have been expected since hydrocarbons, especially PAHs, whose reactive metabolites result in substances more genotoxic than sewage compounds, aresubject to biotransformation. In experiments carried out by PHAN et al., (2007), the authors compared the data of fish Tramatomus newnesi caged for 12 days in waters in front of fuel tanks and sewage outflow, with those from a laboratory bioassay, where groups of fish were exposed to waters from the same places. According to these authors, the differences in the amounts of micronucleus and erythrocyte abnormalities found in the laboratory between thefish fromthe two sites were due to the fact that in the laboratory, the fish were exposed to the water in such a way as to preserve their spontaneous characteristics, asituation opposite to that of the caged fish, in which differences in the genotoxicity were not significant between places due to mixing processes. The FT and STO sites are less than $100 \mathrm{~m}$ apart, thus, depending on the mixing process of the shallow waters between these areas, animals are subject to the environmental pollution of substances, such as PAHs that caused the similar results observed.

Even in the biomonitorings I and II, where differences between places are not significant, the DNA damage of G.antarcticatends to be higher at the FT and STO sites than at the control sites. Further, damage to the DNA of hemocytes peaked at FT, probably resulting from the prompt exposure to the high levels of PAHs in the sediments of this site (BÍCEGO et al., 1998; MARTINS, et al., 2004).

Comparisons between the biomonitorings were undertaken in order to evaluate the reliability of results. A general decreasing tendency can be seen in the DNA damage of animals when the biomonitorings I, II and III at the four sites arecompared (Fig. 3). This tendency may be attributed to the inherent variabiality of the data as a consequence of the physiological status of the animals, as regards the stress of capture. However, this tendency was significant only at the PPL site. In addition, values of the biomonitorings at the PPL site were lower than their respective values at the other sites. For the YP, FT and STO sites, thedamage to the DNA of thehemocytes of $G$. antarctica peaked in biomonitoring IV, the highest value being found at the FT site.

Table 1. Range of sewage organic compounds and hydrocarbons in sediments of the shallow waters (0-10 m depth) in front of the Brazilian Antarctic Research Station EACF and neighbor areas.

LABs: linear alkylbenzenes; $\Sigma$-AHs: total aliphatic hydrocarbons; $\Sigma$-PAHs: total polycyclic aromatic hydrocarbons; n.a.: not available.

\begin{tabular}{|c|c|c|c|c|}
\hline Reference & $\begin{array}{c}\text { Faecal sterols } \\
\mu \mathrm{g}_{-} \mathrm{g}^{-1}\end{array}$ & $\begin{array}{l}\text { LABs } \\
\text { ng-g }^{-1}\end{array}$ & $\begin{array}{l}\Sigma \text {-Ahs } \\
\mu \mathrm{g}^{-\mathrm{g}^{-1}}\end{array}$ & $\begin{array}{c}\sum \text {-PAHs } \\
n g-g^{-1}\end{array}$ \\
\hline Bícego et al., 1998 & n.a & n.a. & $0.14-0.58$ & $1.00-32.0$ \\
\hline Martins et al., 2002 & $0.21-10.4$ & $<0.60-11.8$ & n.a. & n.a. \\
\hline Martins et al., 2004 & n.a & n.a & $0.15-13.28$ & $9.45-270.5$ \\
\hline Martins et al., 2010 & $0.01-0.95$ & $1.00-23.0$ & n.a. & n.a. \\
\hline Martins et al., 2012 & $0.01-0.17$ & $1.00-46.5$ & n.a. & n.a \\
\hline
\end{tabular}




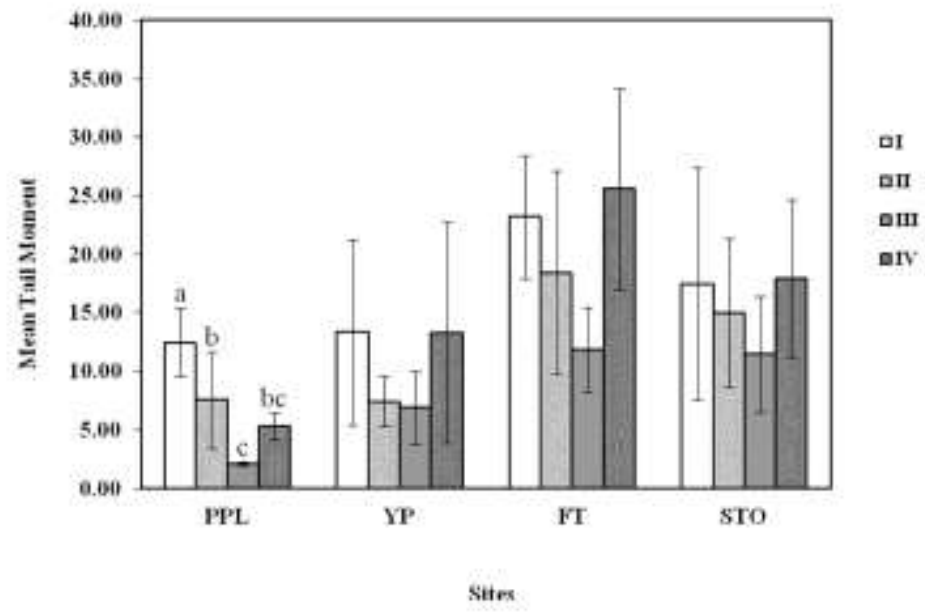

Fig. 3. Mean $( \pm \mathrm{SD})$ Tail Moment of hemocytes DNA of Gondogeneia antarctica at the same sampling places at different biomonitorings. Different letters denote significant differences $(\mathrm{p}<0.05)$ between the biomonitorings.

The results presented thus far emphasize the importance of biomonitoring the shallow waters near research stations in order to assess the environmental impact of the human presence on Antarctic ecosystems. The amphipod G. antarctica responded satisfactorily as a bioindicator of aquatic pollution, as also did the comet assay as a tool for the assessment of genotoxicity through the assessment of the DNA damage to itshemocytes.

\section{ACKNOWLEDGEMENTS}

This study forms part of the National Institute of Science and Technology's Antarctic Environmental Research project (INCT-APA) that receives scientific and financial support from the National Council for Research and Development (CNPq process: $n^{\circ}$ 574018/2008-5) and the Carlos Chagas Research Support Foundation of the State of Rio de Janeiro (FAPERJ $\mathrm{n}^{\circ}$ E-16/170.023/2008). The authors also acknowledge the support received from the Brazilian Ministries of Science, Technology and Innovation (MCTI), of the Environment (MMA) and the Inter-Ministerial Commission for Marine Resources (CIRM). Our special thanks go to the Oceanographic Institute of the University of São Paulo (IOUSP), and all the members of the INCTAPA.

\section{REFERENCES}

ANDERSON, S.; SADINSKY, W.; SHUGART, L.; BRUSSARD, P.; DEPLEDGE, M.; FORD, T.; HOSE,
H.; STEGEMANT, J.; SUK, W.; WIRGIN, I.; WOGAN, G. Genetic and molecular toxicology: a research framework. Environ. Health Perpect., v. 102, n.12, p. 3-8, 1994.

BARRERA-ORO, E.; PIACENTINO, G. Feeding habits of juvenile Trematomus newnesi (Pisces, Nototheniidae) at the Potter Cove, South Shetland Islands, Antarctica. Polar Biol. v. 30, p. 789-796, 2007.

BARRERA-ORO, E. R.; WINTER, D. J. Age composition and feeding ecology of early juvenile Notothenia rossii (Pisces, Nototheniidae) at the Potter Cove, South Shetland Islands, Antarctica. Antarct. Sci., v. 20, p. 239241, 2008.

BÍCEGO, M. C.; WEBER, R. R.; ITO, R. G. Aromatic hydrocarbons on (in?) surface waters of Admiralty Bay, King George Island, Antarctica. Mar. Pollut. Bull., v. 32 n. 7, p. 549-553, 1996.

BÍCEGO, M. C.; ZANARDI, E.; ITO, R. G.; WEBER, R. R. Hydrocarbons in surface sediments of Admiralty Bay, King George Island, Antarctica. Pesquisa Antártica Brasileira, v.3, p. 15-21, 1998.

BÍCEGO, M. C.; ZANARDI-LAMARDO, E.; TANIGUCHI, S.; MARTINS, C. C.; SILVA, D. A. M.; SASAKI, S. T.; BARBOSA, A. C. R. A.; PAOLO, F. S.; WEBER, R. R.; MONTONE, R. C. Results from a 15-year study on hydrocarbon concentrations in water and sediment from Admiralty Bay, King George Island, Antarctica. Antarct. Sci., v. 21, n. 3, p. 209-220, 2009.

BIHARI, N.; FAFANĐEL, M. Interspecies differences in DNA single strand breaks caused by benzo[a]pyrene and marine environment. Mutat. Res., v. 552, p. 209-217, 2004.

BOURRET, V.; COUTURE, P.; CAMBELL, P. G. C.; BERNATCHEZ, L. Evolutionary ecotoxicology of wild yellow perch (Perca flavescens) populations chronically exposed to a polymetallic gradient. Aquat. Toxicol., v. 86, p. 76-90, 2008. 
COLLINS, A. R. The comet assay for DNA damage and repair: Principles, Applications, and Limitations. Mol. Biotechnol., v. 26, n. 3, p. 249-261, 2004.

CRIPPS, G. C.; PRIDDLE, J. Hydrocarbons in the Antarctic marine environment. Antarct. Sci., v. 3, n. 3, p. 233-250, 1991.

DE BOECK, M.; KIRSCH-VOLDERS, M. Nereis vireis (Annelida: Polychaeta) is not an adequate sentinel species to assess the genotoxic risk (comet assay) of PAH exposure to the environment. Environ. Mol. Mutagen., v. 30, p. 82-90, 1997.

FREIRE, A. S.; ABSHER, T. M.; CRUZ-KALED, A. C.; KERN, Y.; ELBERS, K. L. Seasonal variation of pelagic invertebrate larvae in the shallow antarctic waters of Admiralty Bay (King George Island). Polar. Biol., v. 29, n. 4, p. 294-302, 2006.

GARCÍA, O.; MANDINA, T.; LAMADRID, A. I.; DIAZ, A.; REMIGIO, A.; GONZALEZ, A.; PILOTO, J.; GONZALEZ, J. E.; ALVAREZ, A. Sensitivity and variability of visual scoring in the comet assay. Results of an inter-laboratory scoring exercise with the use of silver staining. Mutat. Res., v. 556, p. 25-34, 2004.

GARCÍA, O.; ROMERO, I.; GONZALEZ, J. E.; MANDINA, T. Measurements of DNA damage on silver stained comets using free Internet software. Mutat. Res., v. 627, p. 186-190, 2007.

GOMES, V.; PASSOS, M. J. A. C. R.; LEME, N. M. P.; SANTOS, T. C. A.; CAMPOS, D. Y. F.; HASUE, F. M.; PHAN, V. N. Photo-induced toxicity of anthracene in the Antarctic shallow water amphipod, Gondogeneia antarctica. Polar Biol. v. 32, p. 1009-1021, 2009.

GOMES, V.; PASSOS, M. J. A. C. R.; SANTOS, T. C. A.; CAMPOS, D. Y. F.; USSAMI, K. A.; HASUE, F. M.; PHAN, V. N. DNA strand breaks in caged coastal fishes (Trematomus newnesi), following exposure to the waters in front of the Brazilian Antarctic Research Station "Comandante Ferraz", King George Island. Pesquisa Antártica Brasileira., v. 5, p. 61-70, 2012.

HARTL, M. G. J.; KILEMADE, M.; SHEEHAN, D.; MOTHERSILL, C.; O’HALLORAN, J.; O’BRIEN, N. M.; VAN PELT, F. N. A. M. Hepatic biomarkers of sediment-associated pollution in juvenile turbot, Scophthalmus maximus L. Mar. Environ. Res., v. 64, n. 2, p. 191-208, 2007.

HARTMANN, A.; AGURELL, E.; BEEVERS, C.; BRENDLER-SCHAAB, S.; BURLINSON, B.; CLAY, P.; COLLINS, A.; SMITH, A.; SPEIT, G.; THYLAND, V.; TICE, R. R. Recommendations for conducting the in vivo alkaline Comet assay. Mutagenesis, v. 18, n. 1, p. 45-51, 2003.

HUGHES, K. A. Reducing sewage pollution in the Antarctic marine environment using a sewage treatment plant. Mar. Pollut. Bull., v. 49, p. 850-853, 2004.

HUGHES, K. A.; THOMPSON, A. Distribution of sewage pollution around a maritime Antarctic research station indicated by faecal coliforms, Clostridium perfringens and faecal sterol markers. Environ. Pollut., v. 127, p. 315-321, 2004.

JAZDZEWSKI, K. Amphipoda. In: Rakusa-Suszczewski, S. (Ed.). The maritime Antarctic coastal ecosystem of Admiralty Bay. Warsaw: Polish Academy of Sciences, 1993. p.108-116.
JAMES, M. O.; BOYLE, S. M. Cytochromes P450 in crustacea. Comp. Biochem. Physiol., v. 121C, p. 157$172,1998$.

JHA, A. N.; DOGRA, Y.; TURNER, A.; MILLWARD, G. E. Impact of low doses of tritium on the marine mussel Mytilus edulis: genotoxic effects and tissue-specific bioconcentration. Mutat. Res., v. 586, p. 47-57, 2005.

KING, C. K.; RIDDLE, M. J. Effects of metal contaminants on the embryonic and larval development of the common Antarctic sea urchin Sterechinus neumayeri (Meissner).Mar. Ecol.: Prog. Ser., v. 215, p. 143-154, 2001.

KLOBUČAR, G. I. V.; PAVLICA, M.; ERBEN, R.; PAPES, D. Application of the micronucleus and comet assays to mussel Dreissena polymorpha haemocytes for genotoxicity monitoring of freshwater environments. Aquat. Toxicol., v. 64, p. 15-23, 2003.

KUZMICK, D. M.; MITCHELMORE, C. L.; HOPKINS, W. A.; ROWE, C. L. Effects of coal combustion residues on survival, antioxidant potential, and genotoxicity resulting from full-lifecycle exposure of grass shrimp (Palaemonetes pugio Holthuis). Sci. Total Environ., v. 373, n. 1, p. 420-430, 2007.

LEE, R. F.; STEINERT, S. Use of the single cell gel electrophoresis/comet assay for detecting DNA damage in aquatic (marine and freshwater) animals. Mutat. Res., v. 544, p. 43-64, 2003.

LEMIERE, S.; COSSU-LEGUILLE, C.; BISPO, A.; JOURDAIN, M. J.; LANHERS, M. C.; BURNEL, D.; VASSEUR, P. DNA damage measured by the single-gell electrophoresis (Comet) assay in mammals fed with mussels contaminated by the "Erika" oil-spill. Mutat. Res., v. 581, p. 11-21, 2005.

LISKA, D. J. The detoxification enzyme systems. Altern. Med. Rev., v. 3, p. 187-198, 1998.

LIVINGSTONE, D. R. The fate of organic xenobiotics in aquatic ecosystems: quantitative and qualitative differences in biotransformation by invertebrates and fish. Comp. Biochem. Physiol., v. 120, p. 43-49, 1998.

MARTÍN-DÍAZ, M. L.; BLASCO, J.; SALES, D.; DEL VALLS, T. A. Field validation of a battery of biomarkers to assess sediment quality in Spanish ports. Environ. Pollut., v. 151, n. 3, p. 631-640, 2008.

MARTINS, C. C.; VENKATESAN, M. I.; MONTONE, R. C. Sterols and linear alkylbenzenes in marine sediments from Admiralty Bay, King George Island, South Shetland Islands. Antarct. Sci., v. 14, n. 3, p. 244-252, 2002.

MARTINS, C. C.; BÍCEGO, M. C.; TANIGUCHI, S.; MONTONE, R. C. Aliphatic and polycyclic aromatic hydrocarbons in surface sediments in Admiralty Bay, King George Island, Antarctica. Antarct. Sci., v. 16, n. 2, p. 117-122, 2004.

MARTINS, C. C.; AGUIAR, S. N.; BÍCEGO, M. C.; MONTONE, R. C. Sewage organic markers in surface sediments around the Brazilian Antarctic station: Results from the 2009/10 austral summer and historical tendencies. Mar. Pollut. Bull., v. 64, n. 12, p. $2867-$ 2870,2012

MONTONE, R. C.; TANIGUCHI, S.; WEBER, R. R. Polyclorinated biphenyls in marine sediments of Admiralty Bay, King George Island, Antarctica. Mar. Pollut. Bull., v. 42, p. 611-614, 2001. 
MONTONE, R. C.; MARTINS, C. C.; BÍCEGO, M. C.; TANIGUCHI, S.; DA SILVA, D. A. M.; CAMPOS, L. S.; WEBER, R. R. Distribution of sewage input in marine sediments around a maritime Antarctic research station indicated by molecular geochemical indicators. Sci Total Environ., v. 408, p. 4665-4671, 2010.

NONATO, E. F.; BRITO, T. A. S.; PAIVA, P. S.; PETTI, M. A. V.; CORBISIER, T. N.Benthic megafauna of the nearshore zone of Martel Inlet (King George Island, South Shetland Islands, Antarctica): depth zonation and underwater observations. Polar Biol., v. 23, n. 8, p. 580$588,2000$.

OHE, T.; WATANABE, T.; WAKABAYASHI, K. Mutagens in surface waters: a review. Mutat. Res., v. 567, p. 109$149,2004$.

OPALINSKI, K. W.; JAZDZEWISKI, K. Respiration of some Antarctic amphipods. Polskie Archiwum Hydrobiologii., v. 25, p. 643-655, 1978.

OPALINSKI, K. W.; SICINSKI, J. Oxygen consumption in Antarctic tidal zone amphipods. Polskie Archiwum Hydrobiologii., v. 42, p. 537-546, 1995.

PHAN, V. N.; GOMES, V.; PASSOS, M. J. A. C. R.; USSAMI, K. A.; CAMPOS, D. Y. F.; ROCHA, A. J. S.; PEREIRA, B. A. Biomonitoring of the genotoxic potential (micronucleus and erythrocyte abnormalities assay) of the Admiralty Bay water surrounding the Brazilian Antarctic Station "Comandante Ferraz", King George Island. Polar Biol., v. 30, p. 209-217, 2007.

RAJAGURU, P.; SUBA, S.; PALANIVEL, M.; KALAISELVI, K. Genotoxicity of a polluted river system measured using the alkaline comet assay on fish and earthworm tissues. Environ. Mol. Mutagen., v. 41, p. 85-91, 2003.

RIBEIRO, A. P.; FIGUEIRA, R. C. L.; MARTINS, C. C.; SILVA, C. R. A.; FRANÇA, E. J.; BÍCEGO, M. C.; MAHIQUES, M. M.; MONTONE, R. C. Arsenic and trace metal contents in sediments profile from the Admiralty Bay, King George Island, Antarctica. Mar. Pollut. Bull., v. 62, p. 192-196, 2011.

ROCHA, A. J. S.; SANTOS, T. C. A.; GOMES, V.; BÍCEGO, M. C.; BARBOSA, A. C. R. A.; PASSOS, M. J. A. C. R.; HASUE, F. M.; PHAN, V. N. Assessment of trophic transfer of benzo $(a)$ pyrenegenotoxicity from the post-larval pink shrimp $F$. brasiliensis to the juvenile Florida pompano T. carolinus. Environ. Toxicol. Phar., v. 34, p. 969-976, 2012a.
ROCHA, A. J. S.; GOMES, V.; PASSOS, M. J. A. C. R.; HASUE, F. M.; SANTOS, T. C. A.; BÍCEGO, M. C.; TANIGUCHI, S.; PHAN, V. N. EROD activity and genotoxicity in the seabob shrimp Xiphopenaeus kroyeri exposed to benzo[a]pyrene $(\mathrm{BaP})$ concentrations. Environ. Toxicol. Phar., v. 34, p. 995-1003, 2012b.

SANTOS, I. R.; SILVA-FILHO, E. V.; SCHAEFER, C. E. G. R.; ALBUQUERQUE-FILHO, M. R.; CAMPOS, L. $\mathrm{S}$. Heavy metal contamination in coastal sediments and soils near the Brazilian Antarctic Station, King George Island. Mar. Pollut. Bull., v. 50, p. 185-194, 2005.

SANTOS, I. R.; SILVA-FILHO, E. V.; SCHAEFER, C.; SELLA, S. M.; SILVA, C. A.; GOMES, V.; PASSOS, M. J. A. C. R.; PHAN, V. N. Baseline mercury and zinc concentrations in terrestrial and coastal organisms of Admiralty Bay, Antarctica. Environ. Pollut., v. 140, p. 304-311, 2006.

SINGH, N. P.; MCCOY, M. T.; TICE, R. R.; SCHNEIDER, E. L.A simple technique for quantitation of low level of DNA damage in individual cells. Exp. Cell Res., v. 175, p. 184-191, 1988.

TABAN, I. C.; BECHMANN, R. K.; TORGRIMSEN, S.; BAUSSANT, T.; SANNI, S. Detection of DNA damage in mussels and sea urchins exposed to crude oil using comet assay. Mar. Environ. Res., v. 58, p. 701-705, 2004.

TICE, R. R. The single cell gel/comet assay: a microgel electrophoretic technique for the detection of DNA damage and repair in individual cells. In: Phillipos, D.H.; Venitt, S. (Eds.). Environmental Mutagenesis. Oxford: BIOS Scientific Publishers, 1995. p.315-339.

VERMEULEN, N. P. E. Role of metabolism in chemical toxicity. In: Ioannides C. (ed.) Cytochromes P450: Metabolic and Toxicological Aspects. Boca Raton, FL: CRC Press, 1996. p. 29-53.

WEBER, K.; GOERKE, H. Persistent organic pollutants (POPs) in Antarctic fish: levels, patterns, changes. Chemosphere, v. 53, p. 667-678, 2003.

(Manuscript received 28 April 2014; revised 26 October 2014; accepted 03 November 2014) 